\title{
KURIKULUM PESANTREN DALAM PERSPEKTIF GUS DUR; SUATU KAJIAN EPISTEMOLOGIS
}

\author{
Abdullah \\ (STIT Al Ibrohimy Galis Bangkalan)
}

\begin{abstract}
Abstrak:
Penelitian ini bertujuan untuk mendekripsikan tentang sepak terjang pemikiran KH. Abdurrahan Wahid (Gus Dur) tentang pesantren terkhusus kajian epistimologis tentang kurikulum pesantren. Dalam penelitian ini, penulis menggunakan pendekatan dan jenis penelitian kajian literatur, melalui literatur-literatur yang menjelaskan sejarah dan pemikiran Gus Dur. Hasil dari penelitian ini adalah, secara geneaolgi, struktur keilmuan pesantren yang sekarang ini merupakan hasil dialektika antara dua kelompok besar dalam arus intelektualitas Islam di masa awal, yaitu hasil kombinasi sikap humanisme dan hasil serapan dari nalar berfikir filosofi Yunani yang sudah mengakar di Timur Tengah sejak agresi Sultan Iskandaria. Menurut Gus Dur, pesantren adalah lembaga yang berani mengambil lompatan pemikiran ala filosofi Yunani, namun di sisi yang lain mereka tetap mengedepankan al-Qur'an dan Hadith. Berdasarkan kajian epistemologisnya, kitab kuning difungsikan oleh kalangan pesantren sebagai referensi nilai universal dalam menyikapi segala tantangan kehidupan. Kitab kuning dipahami sebagai mata rantai keilmuan Islam yang dapat bersambung hingga pemahaman keilmuan Islam masa tabi'in dan sahabat hingga sampai pada Nabi Muhammad. Dalam pandangan Gus Dur, pesantren harus menjadikan ilmu agama sebagai dasar, tanpa meninggalkan pengetahuan yang lain agar santri lebih dapat mengembangkan potensi dirinya.
\end{abstract}

Kata Kunci: Kurikulum Pesantren, Kaum Santri, Gus Dur, Epistemologi 


\begin{abstract}
:
This research is proposed to describe the thought of $\mathrm{KH}$. Abdurrahman Wahid (Gus Dur) regarding Pesantren, especially the epistemological discourse on its curriculum. In this research, the author uses library research dealing with literature on history and thought of Gus Dur. The result of the study shows that contemporary Pesantren's structure of knowledge is a dialectical result of two mainstreams in the early Islamic periods, involving humanism and adoption of helenestical tradition in the Middle East after the aggression of Alexandrian Sultanate. According to Gus Dur, pesantren is an institution taking a giant leap in thought a la Helenistic periods without putting aside the Qur'an and Hadits. Epistemologically, the yellow scripture takes a role as universal values in human life for pesantren disciples. The scripture is understood as a chain of Islamic knowledge from the Prophet and the companions. Gus Dur strongly agree with putting religion as the foundation of Pesantren, but secular knowledge must be taken as well in order to develop the pesantren disciples' self potential.
\end{abstract}

\title{
Keywords: Pesantren Curriculum, Santri, Gus Dur, Epistemology.
}

\section{A. Pendahuluan}

Pesantren hadir untuk merespon terhadap situasi dan kondisi suatu masyarakat yang dihadapkan pada runtuhnya sendi-sendi moral atau bisa disebut perubahan sosial. Didirikannya pesantren adalah untuk menyebar luaskan ajaran universalitas Islam ke seluruh pelosok nusantara. ${ }^{1}$ Menurut Abdurrahman Wahid peranan, pesantren sebagai pelopor transformasi sosial seperti itu memerlukan pengujian mendalam dari segi kelayakan ide itu sendiri, disamping kemungkinan dampak perubahannya terhadap eksistensi pesantren. ${ }^{2}$ Pesantren adalah lembaga pendidikan Islam pertama yang mendukung kelangsungan sistem pendidikan nasional, selama ini tidak diragukan lagi kontribusinya dalam rangka mencerdaskan kehidupan bangsa sekaligus mencetak kader-kader intelektual yang siap untuk mengapresiasikan potensi keilmuannya di masyarakat. ${ }^{3}$

1 Said Aqil Siradj, pesantren Masa Depan, Wacana Pemberdayaan Dan Transformasi Pesantren (Bandung: Pustaka Hidayah, 1999), 202.

2 Abdurrahman Wahid,"Prospek Pesantren Sebagai Lembaga Pendidikan" Dalam Sonhaji Shaleh (terj); Dinamika Pesantren, Kumpulan Makalah Seminar Internasional, The Role of Pesantren in Education and Community Development in Indonesia (Jakarta : P3M, 1988), 279.

${ }^{3}$ Lihat Imam Tolkhah dan Ahmad Barizi, Membuka Jendela Pendidikan; Mengurai Akar Tradisi (Jakarta: Raja Grafindo Persada, 2004).

Jurnal Pendidikan Agama Islam

Volume 4 Nomor 2 Nopember 2016

ISSN(p) 2089-1946\& ISSN(e) 2527-4511

Hal. 228 - 248 
Jika di pandang dari sudut kurikulumnya, apa yang dipelajarinya dalam pesantren sebagai lembaga pendidikan, dapat dikelompokkan menjadi tiga bidang yaitu, Pertama, bidang teknis seperti ilmu falaq, ilmu fiqh, ilmu tafsir, ilmu musthalah hadits, Kedua, bidang hafalan seperti pelajaran Al-Qur'an, ilmu bahasa Arab, Ketiga, bidang ilmu yang bersifat membangun emosi keagamaan, seperti aqidah, tasawuf dan akhlak. Potensi pengembangan masyarakat dan potensi pendidikan merupakan potensi yang sangat besar pengaruhnya teradap keberhasilan pesantren dalam bidang sosial.

Kesadaran di kalangan pesantren muncul untuk mengambil langkahlangkah pembaharuan guna menjawab tantangan dan kebutuhan transformasi sosial dulakukan dengan pembaharuan kurikulum dan kelembagaan pesantren yang berorientasi pada kekinian sebagai respon dari modernitas. Kemampuannya dalam menjaga nilai primordial secara swadaya membuat lemabaga ini menjadi satu-satunya lembaga pendidikan yang mampu bertahan dan memposisikan diri sebagai aktor penting terhadap penyebaran nilai-nilai dalam pranata sosial masyarakat. Maka tidak mengherankan kalau pesantren dianggap sebagai lembaga yang tertutup dan kebal terhadap perkembangan zaman.

Secara kepemimpinan, konseptulasasi lembaga pendidikan pesantren sepenuhnya berada di tangan seorang Kiai, seorang pemimpin karismatik, terhormat dan sangat di patuhi tidak hanya bagi santri melainkan juga sangat berpengaruh bagi masyarakat sekitar.4 Sekian banyak Kiai dengan segala karakter, pemikiran dan ke unikannya satu di antaranya adalah $\mathrm{KH}$. Abdurrahman Wahid atau yang biasa akrab di panggil dengan sebutan Gus Dur. Figur Kiai nyentrik yang gagasan dan pemikirannya banyak di ikuti bahkan menjadi refrensi beberapa ulama' dan intelektual muslim tidak hanya di internal kluarga besar masyarakat nahdiyin melainkan juga menjadi rujukan bagi pemikir Islamologi di dunia.

Membaca pemikiran KH. Abdurrahaman Wahid (Gus Dur) ibarat menguras sumur tua yang tidak akan pernah kering. Unik, berciri khas dan fenomenal. Fenomenal karena Gus Dur selalu menawarkan ide-ide kontroversial bagi nalar logika umum, dikatakan unik karna dalam dirinya melekat berbagai atribut, baik sebagai seorang intlektual ahli ilmu sosial, tokoh lembaga swadaya masyarakat (LSM), budayawan, agamawan sekaligus seorang Kiai. Serta khas karena beliau adalah refresentasi tokoh yang sangat gigih membela kepentingan minoritas agar tidak tertindas, bahkan menjadi kekuatan menindas, serta mengkritik mayoritas

4 Martin van Burinessen, Rakyat Kecil, Islam Dan Politik (Yogjakarta: Yayasan Benteng Budaya, 1985), 18. 
agar tidak bersikap sewenang-wenang karna merasa berkekuatan besar sekaligus menyelamatkan dari perilaku diktator 5 .

Tidak sedikit tanggapan, baik dalam bentuk pemikiran subyektif yang di dasarkan atas kedekan individu. Ataupun tanggapan ilmiah yang kemudian lebih di afirmasikan dalam bentuk buku, kumpulan isai dan karya tulis Gus Dur. itu semua bermunculan sebagai reaksi atas pemikiran Gus Dur yang progresif, dan masih segar karena merupakan wacana baru, bahkan tidak jarang di antaranya dianggap bertentangan dengan pemikiran mayoritas (cosmmon sense) dan membuat orang yang menangkapnya menjadi tertantang untuk merespon atau sekedar mendalaminya. ${ }^{6}$

Dari sekian banyak pendapat atau pun buku yang berisi pemikiran, biografi atau otobiokrafi Gus Dur yang hari ini beredar lebih banyak mengupas seputar tanggapan cucu pendiri NU ini tentang isu-isu Islam secara kontektual dean relasinya dengan Negara, tradisionalisme-modernisme, dan beberapa gagasan politik Gus Dur terkait isu-isu tekini tentang tentang kondisi kenegaraan seperti penegakan Hak Asasi Manusia (HAM), demokrasi dan mempertahankan Negara Kesatuan Repuplik Indonesia (NKRI). Namun, sedikit diantaranya yang mengupas secara konprehensif seputar pandangan cucu pendiri Nahdlotul Ulama' (NU) dan putra menteri agama pertama Indonesia ini tentang dunia pendidikan pesantren.

Padahal masyarakat sudah memahami kalau Gus Dur berasal dari keluarga pesantren. Ia lahir, besar dan berkembang di lingkungan pesantren. Gus Dur adalah orang yang berangkat "dari pesantren" dan semestinya segala produk dan pemikiran juga harus di "kembalikan kepesantren"7. Sejak tahun 1970-an hingga setidaknya ahir tahun 1980-an, Gus Dur gencar menulis dan memberikan prasaran berbagai masalah kepesantrenanyang berkaitan dengan agama, kebudayaaan, ideologi, dan modernisasi. Perlu di katakana bahwa pada saat itu pesantren adalah topik yang sangat menarik ibaratkan wanita molek dan seksi. Pada saat itu pula pesantren di kenal memiliki pola kehidupan yang unik, sebuah pola kehidupan masyarakat subkultur namun juga eksklusif. Dengan berbagai upaya publikasi yang dilakukan oleh Gus Dur tersebut, tidak salah kalau kemudian Muslim Abdurrahman menyebut Gus Dur sebagai " jendela kaum santri". 8

${ }^{5}$ Listiyono Santoso, Teologi Politik Gus Dur (Jogjakarta: Ar-Ruzz, 2004), 9.

${ }^{6} \mathrm{Hal}$ ini lebih dikarenakan pola pemikiran Gus Dur lebih mirip dengan gaya dan karakter pemikiran para intlektual Madzhab Frankfrut bahkan tidak jarang juga ada yang menganggap Gus Dur sebagai pemikir neo-modernisme dan mencoba meletakkannya kedalam katagori pemikir libral. Lihat Listiyono Santoso, Teologi Politik Gus Dur, 31.

${ }^{7}$ Abdurrahman Wahid, Menggerakkan Tradisi (Jogjakarta: LKIS, 2001), vi.

${ }^{8}$ Wahid, Menggerakkan Tradisi, vii. 
Yang menjadi persoalan di sini adalah terdapat waktu yang sangat penjang ketika Gus Dur di kenal sebagai “ jendela kaum santri” di mana saat itu pesantren di anggap esklusif dan tertutup, dengan kondisi realitas faktual hari ini. Di mana Gus Dur lebih akrab dengan sebutan tokoh pluralis dan multikuturalis. Yang menarik untuk di kaji menurut penulis adalah pemikiran KH. Abdurrahman Wahid terkait pandangan tentang persoalan pesantren, dengan pemikirannya yang di anggap controversial karena sarat kritik terhadap kemapaman, menjunjung tinggi kebebasan berfikir dan berpendapat dan konsestensi Gus Dur, yang bahkan telah di anggap melampui akar tradisi pesantrenan sebagai mana wacana tentang modernisasi, libralasi pemikiran dan beberapa gagasannya yang mendorong serta konsisten dalam menegakkan Hak Asasi Manusia (HAM) merupakan kata kunci utama (key word) yang harus di pahami dari sosok Gus Dur yang kemudian di kontestasikan dengan dunia pendidikan pesantren. Secara ilmiah hal ini di lakukan dengan tujuan untuk menemukan wacana baru pemikiran Gus Dur tentang pesantren. ${ }^{9}$

Penelitian ini bergulat dengan refleksi epistemologi pendidikan Islam di Pesantren dalam bentuk deskriptif. Salah satu tujuannya untuk menganalisa epistemologi pendidikan kaum santri dalm sudut pandang pemikiran Gus Dur tentang pesantren, dan pada saat yang sama penelitian ini bermaksud mengurai epistemologinya yang berkontribusi besar bagi eksistensi pesantren tersebut. Dengan bermaksud memformulasikan epistemologi pendidikan pesantren dengan teori-teori yang relevan dengan kajian epistemologinya, khususnya epistemologi pendidikan pesantren dengan narasi deskriptif yang reduksional. Dengan mengintegrasikan diri ke dalam kehidupan modern tanpa terlalu banyak mengorbankan identitas dirinya sendiri.

\section{B. Mengurai Tradisi Keilmuan Pesantren}

Pesantren begitu akrab dengan al-kutub al-qadimah atau lazim disapa dengan sebutan kitab kuning. Kitab kuning merupakan istilah yang dimunculkan oleh kalangan luar pesantren, yang ditengarai sebagai kitab yang memiliki kadar keilmuan yang rendah, out of date, dan penyebab stagnasi keilmuan. Namun kemudian, istilah ini menjadi sangat familiar bagi kalangan pesantren, dan konotasi negatif yang dilekatkan dengan awal kemunculan istilah tersebut perlahan memudar.

Secara umum, kitab kuning dipahami oleh beberapa kalangan sebagai kitab referensi keagamaan yang merupakan produk pemikiran para ulama pada masa

9 Sebagai mana kotestasi pemikiran Gus Dur dengan ciri khasnya yang pruralis, multikulturalis dan memperjuangkan HAM yang lainnya seperti" Islam Kosmo Politan", Islamku, Islammu, Dan Islam Kita Semua" terbitan The Wahid Institute. 
lampau (al-salaf) yang ditulis dengan format khas pra-modern, sebelum abad ke17-an M. Dalam hal ini, kitab kuning menjadi bagian khazanah keilmuan Islam yang sangat berharga. Selama hampir 15 abad, khazanah keilmuan ini tidak pernah putus dan terpelihara secara kokoh. Pesantren mengambil bagiannya sebagai lembaga pendidikan Islam yang telah melestarikan budaya dan tradisi keilmuan klasik ini dengan senantiasa mewariskan kepada santri-santrinya.

Dari sudut pandang ini, peran pesantren patut dihargai. Pesantren dengan berbagai variannya merupakan pusat persemaian dan pusat dipraktekkannya ilmu-ilmu keislaman sekaligus sebagai pusat pembakuan dan penyebarannya. Persoalan apakah "pesantren" merupakan karya budaya asli Indonesia ataukah bentuk lembaga yang diimpor dari Mesir, seperti yang ditengarai Martin Van Bruinessen ${ }^{10}$ tidak menjadi soal. Yang jelas, kontribusi pesantren dalam membentuk dan memelihara khazanah keilmuan Islam klasik sangatlah besar.

Dalam melihat tradisi keilmuan klasik seperti yang dikembangkan di lingkungan pesantren, terdapat dua trend (aliran) pemikiran Islam dari sisi epistemologi yang berkembang. Pertama, adalah trend yang bersikukuh untuk mempertahankan tradisi keilmuan Islam tersebut dan memanfaatkannya untuk memfilter dan membendung dampak negatif dari gerak laju modernisasi. Dalam hal ini, tradisi keilmuan semisal di pesantren, dianggap sebagai budaya keilmuan yang tanpa harus dipertanyakan asal-usulnya, dan timbul kesan bahwa piramida pemikiran Islam yang meliputi ilmu kalam, fiqih, dan tasawuf adalah suatu bentuk bangunan yang paten yang ghăiru qabilin li at-tăghyir wa al-niqas. Kitab kuning dianggap sebagai `produk jadi` dan `produk siap pakai`sehingga generasi berikutnya hanya tinggal mewarisi saja tanpa menggunakan daya nalar kritisnya. ${ }^{11}$

Fenomena semacam ini dapat dilihat, misalnya, pada beberapa forum kajian ala pesantren di Jawa dan Madura semisal bahts al-masail yang mencoba untuk memecahkan setiap persoalan, baik sosial, budaya,ekonomi, hukum maupun politik, dari yang klasik sampai kontemporer, dengan senantiasa merujuk pada kitab kuning. Proses istinbäth al-hukum dilakukan dengan mengambil pendapatpendapat ulama terdahulu dan terkadang melalui teknik ilhāq al-masail bi nādzairiha. Pada konteks ini, pola pemikiran di atas masuk pada ranah madzhab qauli, sedangkan pendekatan yang dilakukan cendrung bersifat normatifteologis, sementara pendekatan historis-kritis kurang mendapatkan perhatian yang proporsional. Dengan begitu tradisi kritik epistemologi nyaris tidak tersentuh oleh model pemikiran yang pertama ini.

${ }^{10}$ Van Bruinessen, Kitab Kuning, Pesantren dan Tarekat, 73.

11 M. Amin Abdullah, Islamic Studies di Perguruan Tinggi Pendekatan Integratif Interkonektif (Yogyakarta: Pustaka Pelajar, 2006), 295. 
Kedua, adalah tradisi pemikiran keagamaan yang bersifat kritis, yang melihat bahwa khazanah keilmuan dan pemikiran keagamaan, semacam kitab kuning, merupakan bagian dari "prudok sejarah" yang sudah barang tentu qobilun li al-tāghyir wa al-niqās.12 Pemikiran Al-`Asy`ari dalam ilmu kalam, AsSyafi i, Hanafi, Maliki dan Hambali yang lain tidak bersifat taken for granted dan mutlak harus diikuti begitu saja tanpa pertanyaan yang kritis. Karena setiap pemikiran pasti dipengaruhi oleh situasi dan kondisi di mana dan kapan pemikiran itu muncul. Piramida tradisi keilmuan yang tercermin dalam ilmu kalam, tasawuf, dan fiqih merupakan hasil rumusan manusia yang tidak luput dari campur tangan ideologi bahkan kondisi politik yang berkembang pada masa itu, meski disana-sini telah dibalut dengan kutipan wahyu atau hadits nabi.

Pola pemikiran yang kedua ini cendrung mengakomodasikan perkembangan ilmu pengetahuan dalam bidang apapun (ilmu alam; fisika, biologi, bio-teknologi, sosial; sosiologi, antropologi, sejarah, dan lain sebagainya) dan memanfaatkan seperlunya untuk menjelaskan kembali konsep-konsep keagamaan yang telah dirumuskan berabad-abad yang lalu. Tradisi keagamaan apa pun dapat, dapat saja ditelaah secara kritis. Jika tradisi tidak boleh dilihat secara kritis-historis, maka menurut alur pemikiran yang kedua ini, secara pelan tapi pasti akan terjadi proses intelectual suicide ${ }^{13}$ (kejenuhan atau bunuh diri intelektual).

Dalam tradisi intelektual Islam, khususnya di Timur Tengah, dikenal dua istilah untuk menyebut kategori karya-karya ilmiah berdasarkan kurun atau format penulisannya. Kategori pertama disebut kitab-kitab klasik (al-kutub alqadimah), sedangkan kategori kedua disebut kitab-kitab Modern (al-qulūb alashriyah). Perbedaan yang pertama dari yang kedua dicirikan, antara lain, oleh cara penulisannya yang tidak mengenal pemberhentian, tanda baca (punctuation), dan kesan bahasanya yang berat, klasik,dan tanpa syakl (harakat). Apa yang disebut kitab kuning pada dasarnya mengacu pada kategori yang pertama, yakni kitab-kitab klasik.14

Kitab kuning difungsikan oleh kalangan pesantren sebagai 'referensi' nilai universal dalam menyikapi segala tantangan kehidupan. Karena itu, kitab kuning harus tetap terjaga. Kitab kuning dipahami sebagai mata rantai keilmuan Islam yang dapat bersambung hingga pemahaman keilmuan Islam masa tabiin dan sahabat hingga sampai pada nabi Muhammad. Makanya, memutuskan mata rantai kitab kuning, sama artinya membuang sebagian sejarah intelektual umat.

${ }^{12}$ Abdullah, Islamic Studies di Perguruan Tinggi Pendekatan Integratif Interkonektif, 298.

13 Fazlurrahman, Membaca Pintu Ijtihad, terj. Mahyuddin, (Bandung: Penerbit Pustaka, 1984), 158.

14 Van Bruinessen, Kitab Kuning, Pesantren dan Tarekat, 234-235. 
Kendatipun demikian, untuk membangun sebuah tradisi keagamaan yang selalu up to date dan tanggap terhadap tantangan dan perubahan zaman maka diperlukan retinking atau pemahaman kitab-kitab kuning secara kontekstual. Pengembangan al-'Ulüm al-Diniyah Melalui Telaah Kitab secara Kontekstual (Siyâqi bahwa takrif pemahaman kitab kuning secara kontekstual adalah; Pertama, suatu proses pemahaman kitab kuning yang mengacu kepada kenyataan baik syahshiyah (individual) maupun ijtima'iyah (sosial) yang melatarbelakangi kehadirannya. Kedua, upaya memahami kitab kuning yang tidak terbatas pada makna-makna harafiah, tetapi mampu menyentuh natîjah (kesimpulan) pemikiran yang menjadi jiwanya. hasil, teks kitab kuning selalu dipahami dalam konteks sintaksis (siyâqul kalâm) dan konteks kesejarahan (siyâqut târîkh) secara sekaligus.

Tegasnya, jika pemikiran ilmu kalam klasik dapat berdialog akrab dengan pemikiran serta epistemologi Yunani (Hallenisme), maka pemikiran keislaman sekarang pun, termasuk kitab kuning, harus mampu berdialog dengan perkembangan ilmu-ilmu modern yang muncul saat ini. Kontekstualisasi pemahaman kitab-kitab kuning dalam upayanya memecah stagnasi keilmuan Islam dan melahirkan tradisi keilmuan yang kritis dapat terjadi jika literatur kitab kuning (al-kutub as-safra') dapat bergaul, bersentuhan langsung dengan literatur kitab putih (al-kutub al-baido'), lantaran di dalam buku-buku itu terdapat hal-hal yang belum terurai secara akademik dalam al-kutub as-sofro .

\section{Gus Dur dan Pesantren; Sepak Terjang Intelektualis Kaum Santri}

Pemikiran seorang tokoh biasanya terlihat pada sejumlah pidato dan karya tulisnya. Untuk itu, pada bagian ini akan dikemukakan sketsa dan sepak terjang pemikiran Gus Dur sebagai sebagai seorang akademisi sekaligus sebagai santri. Gus Dur, menunjukkan sikap optimismenya bahwa pesantren dengan ciri-ciri dasarnya mempunyai kemampuan yang luas untuk melakukan pemberdayaan masyarakat, terutama pada kaum tertindas dan termarjinalkan. Bahkan dengan kemampuan fleksibelnya, pesantren dapat mengambil peran yang signifikan, bukan saja dalam wacana ke agamaan, tetapi dalam seting sosial budaya, bahkan politik dan ideologi sekalipun.

Namun, perlu dicatat bahwa pesantren sekarang di lihat dari segi ruang lingkungan program dan organisasi ke lembagaan sudah tidak lagi sama sepenuhnya dengan model pesantren klasik. Pesantren telah mengalami perubahan dari masa ke masa. Dengan melihat dinamika sistem pendidikan pesantren, tidak mengherankan jika tamatan pesantren sudah dapat melakukan berbagai peran yang demikian besar dalam konstelasi dan percaturan politik, ekonomi, pendidikan, seni, di samping peran ke agamaan, dan lain sebagainya. 
Lahirnya dinamika pesantren yang demikian itu tidak lepas dari gagasan modernisasi dan dinamisasi pesantren yang di lontarkan Gus Dur. Melalui gagasan pembaharuan dan dinamisasi pesantren, Gus Dur menginginkan terjadinya proses penggalakan kembali nilai-nilai positif yang telah ada dan melakukan pergantian nilai-nilai lama yang tidak relefan lagi dengan nilai-nilai baru yang lebih relevan dan di anggap lebih baik dan lebih sempurna untuk menjaga eksistensi pesantren.

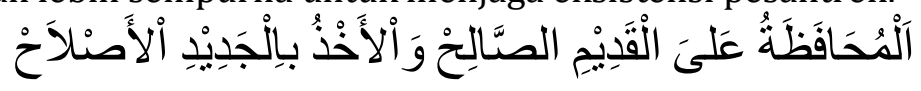

"Memelihara dan melestarikan nilai-nilai lama yang masih relevan dan mengambil nilai-nilai yang baru yang lebih relevan lagi". 15

Gagasan pembararuan pesantren tersebut di atas, Gus Dur juga menyinggung tentang terjadinya kekacauan dalam sistem pendidikan pesantren. Menurutnya, kekacauan ini di sebabkan karna dua hal. Pertama, sebagai refleksi dari kekacauan yang terjadi secara umum di masyarakat Indonesia, sebagaimana masyarakat yang mengalami transisi. Kedua, karena munculnya kesadaran bahwa kapasitas pesantren dalam menghadapi tantangan-tantangan modernitas hampir tidak memadai yang di sebabkan karena unsur-unsur strukturalnya mandeg sehingga tidak mampu menanggapi perubahan. ${ }^{16}$

Selain itu Gus Dur, juga melihat adanya kerawanan pada sistem pesantren yang berakibat pada kekurang siapan pesantren dalam menghadapi tantangan pembaharuan. Gur Dur melihat bahwa kerawanan tersebut melahirkan dua reaksi sebagai berikut. Pertama, bebentuk muculnya sikap menutup diri dari perkembangan umum masyarakat luar, terutama dari kegiatan yang mengancam kemurnian kehidupan beragama. Kedua, timbulnya aksi solidaritas yang kuat di antara masyarakat dan pesantren. ${ }^{17}$

Kedua reaksi yang menggambarkan ketidak berdayaan pesantren tresebut menurut Gus Dur menunjukkan bahwa pesantren tidak memiliki pimpinan yang efektif yang didukung oleh semua pihak. Kurangnya tokoh yang dapat di jadikan panutan pada tingkat nasional, selain menyebabakan terjadinya polarisasi sosialpolitik yang melanda umat Islam, juga telah mempengaruhi watak kepemimpinan pesantren yang selama ini di topeng oleh kekuatan moral.

Sepak terjang pemikiran KH. Abdurrahman Wahid tentang pendidikan pesantren secara jelas terlihat pada gagasannya tentang pembaharuan pesantren. Menurutnya, semua aspek pendidikan pesantren, mulai dari visi, misi,

15Tajudin 'Abdul Wahhab Ibn 'Ali As-Subki, Jam'ul Jawami' Fi Usulil Fiqh (Nairab Damaskus, 771 H), 89.

${ }^{16}$ Abdurrahman Wahid, Menggerakkan Tradisi: Esai-Esai Pesantren (Yogyakarta: LKiS, 2001), 38.

17 Pairin, "Gagasan K.H.Abdurrahman Wahid tentang Modernisasi Pesantren di tengah Arus Globalisasi" (Tesis) (Jakarta: Pascasarjana UMJ, 2004), 131-132. 
tujuan, kurikulum, manajemen dan kepemimpinannya harus diperbaiki dan disesuaikan dengan perkembangan zaman era globalisasi. ${ }^{18}$ Meski demikian, menurut Gus Dur pesantren juga harus mempertahankan identitas dirinya sebagai penjaga tradisi keilmuan klasik, dalam arti tidak larut sepenuhnya dengan modernisasi, tapi mengambil sesuatu yang dipandang manfaat-positif untuk perkembangan.

Selain itu, menurutnya dalam melakukan modernisasi tersebut pesantren juga harus mampu melihat gejala sosial yang tumbuh di masyarakat, sehingga keberadaan pesantren dapat berperan sebagai pusat pengembangan masyarakat. Dengan ini, sebenarnya Gus Dur hendak mengatakan bahwa peran pesantren tidak hanya sebagai lembaga pendidikan keagamaan semata, namun juga mampu memberikan sumbangsih yang berarti serta membangun system nilai dan kerangka moral pada individu dan masyarakat. Dengan cara demikian, pesantren dapat menjadi lembaga pendidikan yang mendidik manusia untuk bisa menjalani kehidupan dalam arti yang sesungguhnya. ${ }^{19}$

Lebih lanjut, berdasar latar ini, menurut Gus Dur pesantren seharusnya menyelenggarakan pendidikan umum. Hal ini dimaksudkan supaya peserta didik yang belajar di pesantren adalah peserta didik yang memiliki ilmu agama yang kuat sekaligus juga memiliki ilmu yang kuat secara seimbang. Gus Dur menginginkan, Agar di samping mencetak ahli ilmu agama Islam, pesantren juga mampu mencetak orang yang memiliki keahlian dalam ilmu pengetahuan dan teknologi yangending berguna untuk perkembangan masyarakat itu sendiri. ${ }^{20}$

Dengan dasar di atas, Gus Dur menginginkan ada perubahan pada kurikulum pesantren. menurutnya, kurikulum pesantren selain harus kontekstual dengan kebutuhan zaman juga harus mampu merangsang daya intelektual-kritis anak didik. Terkait yang terakhir ini semisal dengan melebarkan pembahasan fiqih antar madzhab. Namun, sebagaimana ia tuturkan sebelumnya, bentuk kurikulum tersebut tetap harus dalam asas yang bermanfaat bagi masyarakat dan juga tidak sampai menghilangkan identitas diri pesantren sebagai lembaga pendidikan agama. Dalam arti jangan sampai pesantren mengajarkan ketrampilan saja ataupun sebaliknya, yakni mengajarkan agama saja, tetapi keduanya harus dalam porsi yang seimbang.

Kemudian terkait dengan pembelajaran, Gus Dur menyatakan bahwa pendekatan pembelajaran di pesantren harus mampu merangsang kemampuan

18 Ahkamul Fuqoha, Solusi Problematika Aktual Hukum Islam Keputusan Muktamar, Munas dan Konbes NU (1926-1999) (Surabaya: LTNU Jatim dan Diantama Lembaga Studi dan Pengembangan Pesantren, 2005), 1.

19 Ahkamul Fuqoha, Solusi Problematika Aktual Hukum Islam Keputusan Muktamar, Munas dan Konbes NU (1926-1999), 353.

${ }^{20}$ Abdurrahman Wahid, Pribumisasi Islam (Yogyakarta: LKiS, 1998), 153.

Jurnal Pendidikan Agama Islam

Volume 4 Nomor 2 Nopember 2016

ISSN(p) 2089-1946\& ISSN(e) 2527-4511

Hal. 236 - 248 
berpikir kritis, sikap kretif dan juga merangsang peserta didik untuk bertanya sepanjang hayat. Ia sangat menolak system pembelajaran yang doktriner danbanking yang akhirnya hanya akan membunuh daya eksplorasi anak didik. Sedangkan terkait dengan Guru dan pemimpin menurut Gus Dur harus dilakukan perpaduan antara bercorak karismatik dengan corak yang demokratis, terbuka dan menerapkan manajemen modern. ${ }^{21}$

Kesemua konsep pendidikan anak pertama dari KH. Wahid Hasyim ini sebenarnya sangat dipengaruhi oleh keyakinan dan paradaigmanya, yakni demokrasi, inklusifme agama, dan pembelaannya terhadap kau mmustadl'a fin. Keyakinan- keyakinan ini terlihat jelas dari belantara pemikirannya yang terkodifikasi dalam karya-karyanya, semisal dalam buku Tuhan Tak Pelu Dibela, Islamku Islam Anda. Demikianlah pesantren didefinisikan oleh pengamatnya baik yang barasal dari dalam maupun dari luar pesantren, di mana variasi yang dihasilkan merupakan suatu keniscayaan yang tidak dapat dipungkiri. Hal tersebut disebabkan perbedaan semacam itu, jusrtu semakin menambah khazanah dan wacana yang sangat diharapkan secara akademis.

Gus Dur, juga mengiginkan agar kurikulum pesantren memiliki keterkaitan dengan kebutuhan lapangan kerja. Untuk kalangan dunia kerja, baik dalam bidang jasa maupun dalam bidang perdagangan dan ke ahlian lainnya, pesantren harus bisa memberikan masukan bagi kalangan pendidikan, tentang ke ahlian apayang sesungguhnya di butuhkan oleh lapangan kerja yang di era globalisasi seperti sekarang ini demikian cepat dan beragam. Seiring dengan berubah arah kurikulum di atas, Gus Dur juga menekankan pentingnya menghilangkan dikotomi antara ilmu agama dan ilmu umum, dengan catatan penguasaan ilmu agama harus di beri porsi yang cukup besar dalam kurikulum pesantren tersebut. Porsi tersebut dapat di berikan dalam ukuran besar secara kualitatif dan bukan dalam segi kuantitatif. Dengan kata lain, modernisasi kurikulum pesantren harus tetap berada pada jati dirinya, karena dengan cara demikian itulah, dunia pesantren tidak akan kehilangan jati dirinya. Namun demikian, semua itu pada akhirnya kembali kepada kemauan pengelolanya.

Di dunia pesantren, pemikiran Gus Dur yang demikan ini dianggap telah melampaui batas kulturnya. Maklum khasanah intelektual Islam Indonesia, Gus Dur sering di asosiakan mewakili kelompok tradisional. Dalam konteks ini Gus Dur sendiri sangat menyadari akan kecintaannya terhadap NU sebagai pengusung Islam teradisional, namun kecintaannya ini sangat seimbang dengan

${ }^{21}$ Abudin Nata, Tokoh-tokoh Pembaharuan Pendidikan Islam di Indonesia (Jakarta: Raja Grafindo Persada), 360. 
keinginan untuk menciptakan perubahan dinegeri ini pada tiap level.22 Oleh karena itu, Gus Dur memaknai perubahan atau modernisme sebagai etentitas yang dilatar belakangi sekaligus dimotori oleh semangat tradisionalitas. Tentu dengan pemaknaan modernisme yang demikian inibakan menjadi proses melestarikan dan mengubah. Mengubah tradisi yang menjerumuskan dan tidak bisa mendorong bagi terciptanya perubahan sekaligus menolak peraktek modernitas yang tidak sesuai dengan inti dari nilai-nilai tradisi itu sendiri secara subtantif, atau sebaliknya.

\section{Epistemologi Pendidikan Pesantren}

Epistemologi secara sederhana dapat di artikan sebagai ilmu yang membahas tentang keaslian, pengertian, struktur, metode, dan validasi ilmu pengetahuan.dalam kontek pesantren, secara esensial pesantren berdasarkan diskursusnya pada pada epistemology kitab kuning Kitab kuning difungsikan oleh kalangan pesantren sebagai 'referensi' nilai universal dalam menyikapi segala tantangan kehidupan. Karena itu, kitab kuning harus tetap terjaga. Kitab kuning dipahami sebagai mata rantai keilmuan Islam yang dapat bersambung hingga pemahaman keilmuan Islam masa tabiin dan sahabat hingga sampai pada nabi Muhammad. Makanya, memutuskan mata rantai kitab kuning, sama artinya membuang sebagian sejarah intelektual umat.

Kitab kuning yang dikaji di pesantren tersebut hampir semuanya merupakan ilmu-ilmu yang berbasis pada epistemologi bayani dan 'irfani. Episteme bayani adalah sistem pengetahuan eksplikasi dalam bidang bahasa, fikih, ushul fiqh, kalam, dan balaghah. Sistem eksplikasi muncul dari teori-teori penafsiran teks-teks al-Quran dan hadits. Karakteristik episteme eksplikasi secara umum menggunakan metode analogi. Para ahli hukum dan nahwu menyebutnya dengan istilah Qiyas, para teolog menyebutnya dengan al-istidlal bi al-shahìd (far') 'ala al-ghaib (ashl), sementara ahli balaghah memilih istilah altasybi>h. Sedangkan episteme 'irfani adalah sistem pengetahuan gnostik dalam bidang tasawuf. Epistemologi kitab kuning di pesantren menganut bayani dan 'irfani dalam arti yang sempit; sistem bayani dibatasi pada ilmu-ilmu tekstual Sunni, sementara sistem 'irfani dibatasi pada tasawuf-amali sehingga pesantren menolak tasawuf-falsafi ala Ibn Arabi

Namun pada tingkat yang lebih praktis, hampir seluruh pendidikan pesantren yang ada dijawa selalu berdasarkan pada al-Quran, hadiht, dan kitab kuning dan pemikiran ulama' yang diakui otoritasnya. Secara implisit menunjukkan metode ilmiah yang menjadi salah satu aspek penting dari

22 Abdurrahman Wahid, Gus Dur Bertutur (Jakarta: Harian Proaksi dan Gus Dur Fondation, 2005), xxi. 
pendidikan pondok pesantren itu sendiri. Inlah yang menunjukkan kualitas pendidikan yang ada dalam pesantren.

Sulit sekali dipungkiri, filsafat pendidikan yang diberikan para sarjana dan pemikir pendidikan sepenuhnya adalah filsafat pendidikan Barat, sehingga sistem pendidikan Islam sangat kental oleh pengaruh pendidikan Barat. Sedangkan diketahui bahwa pendidikan Barat dibangun diatas filsafat pendidikan yang sedikit banyak harus diakurkan terlebih dahulu dengan ajaran Islam, karena terkadang anti-metafisika yang menjadi landasan pendidi²3an Barat bertentangan sekali dengan keyakina pendidikan Islam yang kental dengan metafisika. Penulis bermaksud memformulasikan epistemologi pendidikan pesantren terhadap pemikiran Gus Dur yang termasuk kategori tarbawy, yang bukan berarti memulainya dari awal atau mengulang-ulang segudang teori yang membosankan, melainkan memanfaatkan teori-teori yang relevan dengan kajian epistemologinya, khususnya epistemology pendidikan pesantren.

Gus Dur berpendapat bahwa: pesantren adalah kehidupan yang unik, sebagaimana dapat disimpulkan dari gambaran dipesantren dari masa-kemasa mengalami perubahan yang sangat siknifikan yang juga di barengi dengan penampilan menifestasi keilmuannya yang berubah-ubah pula dari waktukewaktu. Walau demikian menurutnya masih dapat di telusuri beberapa hal inti yang masih tetap merupakan tradisi keilmuan pesantren sejak datangnya ke Indonesia hingga saat ini. Terkait dengan hal itu Gus Dur membagi tradisi keilmuan pesantren menjadi tiga bagian utama.

Pertama masa awal yang menurut Gus Dur tradisi keilmuan di pesantren lebih banyak terpengaruh oleh tradisi Hellenisme yang bermula dari proses penjarahan daerah-daerah oleh Iskandar Agung dari makedonia beberapa abad sebelum masehi. Hellenisme ini menurut Gus Dur telah berkembang dengan menyebarkan filsafat yunani yunani keseantero kawasan timur tengah sekaligus meninggalkan pembawaan mistik Dyonisis di yunani kono bercampur dengan semenanjung Asia kecil (Asia Minor) hingga ahirnya dapat membentuk apa yang di kenal dalam agama Kristen sikte-sekte bidat, seperti sekte Nestoria.

Namun sebelum menerangkan terdapatnya indikasi proses penyerapan yang di lakukan peradapan Islam pada masa-masa permulaan dengan peradaban lain di luar Islam termsuk aliran filsafat dan sekte keagamaan, Gus Dur menguraikan secara epistimik, historis dan asal-usul ke ilmuan di pesantren

23 Setidakya itulah yang dapat dijelaskan dari upaya sementara pesantren untuk menyegarkan pandangan keagamaan melalui pembelajaran Islam-nya; sebuah proses pematangan yang dimaksudkan untuk memungkinkan fiqih (atau kemandirian institusional tadi) mengintegrasikan diri ke dalam kehidupan modern tanpa terlalu banyak mengorbankan identitas dirinya sendiri. 
yang bermula dari ajaran al-Qur'an dan hadits untuk mengembangkan ilmu pengetahuan hingga ahirnya menjadi dasar hukum bagi sebagian sehabat untuk mengembangkat perangakat ke ilmuan sendiri. Bagi Gus Dur, hal ini dapat di buktikan dengan kelompok-kelompok yaqng telah melakukan spesialis keilmuan sejak masa kini dari sejarah perjalanan yang cukup panjang

Awal kali berbenturan antara peradaban Islam dan peradaban di luar Islam (terutama peradaban yang berbentuk sebagai hasi dari pergulatan konsesi filsafat yunani baik yang sudah berbentuk dalam skolatisme yahudi atupun nasrani) menurut Gus Dur bermulaa setelah terjadinya perdebatan sengit di internal masyarakat muslim, ketika para ahli baca al-qur'an menekankan pentingnya arti pengambilan harfi dari sumber-sumber pertama al-qur'an dan hadits dalam kata lain memposisikan keduanya sebagai sumber otentik yang tidak dapat di ganggu gugat oleh kelompok lain yang berani melakukan penolakan terhadap sebagian hadits-hadits, yang dalam hal ini menurut Gus Dur walau penulakannya itu tidak pada letter atau bentuk harfiahnya, melainkan pada isi dan kandungan artinya. Dalam hal ini Gus Dur lebih menjelaskan pergulatan tersebut adalah ketika sampai masalah apakah ayat-ayat al-qur'an atau hadits diartikan secara harfi atau boleh diartikan secara allegori (kiasan). ${ }^{24}$ Kalau boleh dilakukan penafsiran secara allegori, dengan sendirinya penafsirannya akan jauh lebih bebas dan lebih merdeka lagi. Sebaliknya menurut Gus Dur, kalau pengertiannya boleh secara harfi, maka penafsiran terhadap arti tersebut juga sedikit banyak akan mengalami keterbatasan. Pertarungan wacana ini kurang lebih berjalan hingga selama 2 abad dan ahirnya menghasilkan kelompok mu'tazilah melawan kelompok sunni atau yang lebih terkenal dengan sebutan ahli sunnah waljamaa'h.

Menurut Gus Dur para ulama' shaleh mulai berani mengambil beberapa keilmuan dari luar untuk dipahami dan diserap sebagai perangkat dasar dan tolak ukur untuk mengartikulasikan al-Qur'an dan hadits secara harfi. ${ }^{25}$

${ }^{24}$ Keduanya merupakan aliran teologi yang muncul sebagai respon menyebarkan aliran Nisbihiyah (orang-orang yang menyamakan Allah dengan mahluk karena menafsiri alqur'an dan hadits sedemikian adanya, misalnya tuhan memiliki mata, telinga atau tangan) aliran Mu'tazilah adalah ke;ompok pemikir ekstrim yang lebih mengedepankan akal dari pada wahyu dipelopori oleh wasil bin atho' dan al-Juba'i. sedangkan aliran sunni atau yang lebih di kenal dengan Ahlu Sunnah Waljama'ah dipelopori oleh abu musa al-asy'ari santri sekaligus anak tiri al-juba'I yang menyatakan keluar dari mu'tazilah atas pendapat mereka yang mengtakan bahwa al-qur'an sebagai mahluq.

25 Metode harfi secara epestimologi bermakna " jalan ke sumber air". Yaitu sebuah metode berfikir secara radikal untuk mengaitkan seluruh persoalan dengan sumber utama keilmuan islam yaitu al-qur'an dan hadits dengan pendekatan kosakata yang menjadi teknis utamnya sehingga menghasilkan kesimpulan yurispundensif (hukum syar'i) seperti yang dilakukan oleh syafii sebagai contoh proses intektualitas islam

Jurnal Pendidikan Agama Islam

Volume 4 Nomor 2 Nopember 2016

ISSN(p) 2089-1946\& ISSN(e) 2527-4511

Hal. 240 - 248 
Kombinasi dari sikap humanisme seperti itu dan kecendrungan normative untuk memperlakukan al-qur'an dan hadits sebagai sumber formal, dengan sendirinya dapat membentuk syistem tradisi keilmuan baru yang unik. ${ }^{26}$ Inilah yang menurut Gus Dur merupakan akar utama sumber keilmuan di pesantren. Namun demikian Gus Dur mengakui semua itu menjadi kendur, ketika kendala normatif akhirnya menjadi terlalu besar fungsinya dan syistem penyerapan fungsinya-pun mulai meredup dikalahkan oleh pengawasan dari dalam. Dan mengatakan “ ahirnya yang ada hanyalah ilmu-ilmu yang sangat normatif yang tidak memberikan tempat dan perhatian dan perhatian pada kebutuhan penciptaan rasionalitas ilmiah yang tersendiri dan independent. Kedua tradisi keilmuan di pesantren yang bersifat fiqhih sufistik yang dalam hal ini menurut Gus Dur terbentuk dan bersumber pada gelombang pertama pengetahuan keislaman yang datang kekawasan nusantara pada masa abad ke 13 Masehi, bersamaan ketika masuknya Islam kekawasan ini.

Dikatakan bersifat fiqhih sufistik, menurut Gus Dur dikarenakan corak dan karakter Islam pertama kali masuk keindonesia lebih menekankan konsep pentauhidan dan pengamalan-pengamalan ilmu syari'ah secara sufisme, hal ini dikaranakan tidak bisa lepasnya pengaruh proses penyebaran islam kenegara ini melalui Persia dsn anak benua India yang dalam beragama lebih menekankan pada orientasi tasawuf. Selain itu, hal ini juga dikarenakan adanya kesamaan (indigenous) antar pemikiran sufisme para penyebar Islam ke Nusantara dengan watak mistik masyarakat indonesia pra Islam.

Hal ini bisa dapat kita lihat dari beberapa literatur pesantren yang lebih banyak menggunakan buku-buku tasawuf dengan menggabungkan fiqhih serta amalan-amalan akhlaq dijadikan bahan pelajaran utama, diantaranya menurut Gus Dur kitab Hidayah al- Hidayah dari imam al- Ghazali yang merupakan karya

yang berhasil ketika mensentesiskan antara madzhab hukum literis dimana tempat ia wafat dan madzha Abu Hanifah. Black juga menambahkan bahwa m etode ini merupakan corak pandangan utama kelompok sunni terutama digunakan untuk menetapkan hukum syari'at. Lihat Abdullah Ali dkk, Pemikiran Politik Islam dari Masa Nabi Hingga Masa Kini (Jakarta: Serambi Ilmu Semesta, 2001), 97.

${ }^{26}$ Unik menurut Gus Dur karena satu pihak karana mereka merupakan sarjana (scolar) yang mempunyai repotasi ilmu yang hebat, tetapi dari segi yang lain mereka tetap manusia-manusia yang tetap beribadah kepada Allah dan tidak luntur imannya di tengah proses penyerapan yang begitu massif akan peradaban-peradaban lain. Dari sini melahirkan nama-nama besar dalam kamus pesantren al-Khalil ibn Ahmad al-Farahidi (penulis kamus arab pertama: mu'jam al-Ain) yang mampu melahirkan imam Sibawaih rujukan ilmu bahasa pesantren, ibnu Qutaibah al- Dinawari (pengarang kitab ta'wil muskil al-qur'an, tafsir ghorib al-qur'an juga mengkaji beberapa hadits kontraversi: Ta'wil Mukhtalaf al-Hadits), yang menurut Gus Dur Ulama' ini sering di baca salah dengan sebutan "Dainuri" hingga menjadi menjadi nama kebanyakan orang indonesia" Zainuri” dan lain sebagainya. Wahid, Menggerakkan Tradisi, 126. 
fiqhih sufistik paling menonjol dalam berabad-abad bahkan hingga saat ini. ${ }^{27}$ Selain itu terdapat pula buku yang mementingkan pendalaman akhlaq dalam bentuk pengamalanya secara tuntas dan pendalaman pemahaman secara sufistik kepada ranah kehidupan yaitu syarh al-Hikam karya Ibn Atha'illah alAskandary.28

Ketiga akar tradisi keilmuan di pesantren yang bersumber pada pengiriman anak-anak muda dari kawasan Nusantara untuk belajar di timur tengah dan ahirnya mereka menghasilkan korp ulama' yang tangguh dan mendalami ilmu agama di semenanjung arabiya, terutama di Makkah. Dari sinilah lahirlah ulama'-ulama' besar seperti Kiai Nawawi Banten, Kiai Mahfud Termas, Kiai Abdul Ghoni, Kiai Arsyad Banjar, Kiai Abdus Shomad Palembang, Kiai Hasyim As'ary Jombang Kiai Kholil Bangkalan, dan beberapa deretan ulama' lain yang sampai sekarang tidak putus karena banya di antaranya selain menetap di timur tengah, mereka yang kembali ke tanah air kemudian mendirikan pesantren.

\section{E. Pergulatan Kurikulum Pendidikan Pesantren; Kajian Epistemologis}

Sebagai intelektual Gus Dur, ingin membuka sebuah fakta yang hari ini terjadi serius dalam dunia keilmuan pesantren, yaitu sebuah akar tradisi keilmuan yang mencoba mengaktualisasikan al-Qur'an dan hadits dengan perangkat pemahaman yang serba konsep sekaligus disisi lain para ilmuan

27 Walaupun pada kenyataan, dalam perjalanan sejarahnya yang panjang sejak abad 13 , yaitu selama 7 abad ia berkembang dipesantren menefistasi keilmuan semacam ini bertumpang tindih dengan pandangan dan perilaku mistik orang jawa atau masyarakat setempat, menurut Gus Dur seperti paham wahdaniyah atau wahdatul wujud, terjadinya peradaban antara ar-Raniry dan gurunya hinggaq menghasilkan "pemurnian" ajaran tasawuf di aceh pada abad ke-16 ini menunjukkan dengan jelas bahwa manifestasi fiqhih sufistik keseluruhan kehidupan orang islam. Bahkan menurut Gus Dur didalam manifestasikehidupan kelompok-kelompok pembaharuan sekalipun seperti gerakan Muhammadiyah, pengaruh tasawuf dalam bentuk akhlaq atau akhlaq sufi begitu kuat. Seperti di buktikan oleh seorang antropolog Jepan Mitsuo Nakamura yang mengalqmi kesulitan dalam membedakan penganut sufi bertarekat dan warga pembaharu yang berakhlaq sufi tampa mengikuti salah satu tarikat. Sebagaimana dikutip Abdurrahman Wahid, Menggerakkan Tradisi, 192.

28 Yang salah satu peninggalan al-hikam adalah kata "nahdhoh" ysang kemudian di artikan kebangunan dengan kalimat "La tashab man la yunhidhuka ila'Allah haluh, wala yadulluka ila 'Allah maqaluh, Artinya " janganlah bersahabat dengan orang yang dalam hal ikwalnya tidak membangkitkan kamu kepada allah, dan janganlah kamu berteman dengan orang yang ucapan-ucapanya tidak menunjukkan kamu ke allah, maksud Gus Dur mengemukakan hal ini, dengan tampa sadar kata " Nahdah" kemudian mejadi kata dalam sebuah organisasi besar para Ulama' di kemudian hari yaitu Nahdhatul Ulama' (NU) sekali lagi ini emnunjukkan bukti betapa kuatnya akar tradisi fiqhih sufistik dalam menjadi pandangan dan dasar keilmuan pesantren. Abdurrahman Wahid, Menggerakkan Tradisi, 129.

Jurnal Pendidikan Agama Islam

Volume 4 Nomor 2 Nopember 2016

ISSN(p) 2089-1946\& ISSN(e) 2527-4511

Hal. 242 - 248 
tersebut masih berpegang teguh pada normatifitas ritual agama yang telah ada secara turu temurun. Inilah yang di maksud Gus Dur sebagai ilmuan humanis yang sholeh (Shaleh humanis). ${ }^{29}$ Nilai yang terkandung dalam tradisi keilmuan pesantren yang biasa disebut indegous latar sosial masyarakat setempat) atau sekedar rekomendasi para pemimpin pesantren dalam bentuk dukungan karena perubahan tersebut tidak bertentangan dengan tradisi keilmuan pesantren secara historis, sosiologis ataupun epistimologis (secara literel perubahan yang yang akan dilakukan mengambil referensi dari kitab-kitab utama yang menjadi pegangan masing-masing pesantren). Proses yang semacam ini, dengan sendirinya akan menimbulkan dialog antara pembaharuan tradisi dan kebutuhan yang akan dijadikan sebagai etentitas baru. Lebih afirmatif lagi, terkait dengan keilmuan pesantren Gus Dur mencontohkan terdapat tiga elemen dasar yang menjadi wilayah berpotensi tinggi untuk dilakukan rekontruksi secara besarbesaran oleh Gus Dur disebut sengan "wilayah rawan”.

Pertama sistem pembelajaran di pesantren, mulai dari orientasi, hingga kurikulum (materi pembelajaran). Dalam hal ini Gus Dur mencontohkan dukungan terhadap pesantren yang ingin membuka "sekolah umum" bahkan sekolah kejuruan dengan asumsi bahwa tidak semua santri bisa dicetak menjadi ahli agama atau ulama' sekaligus mampu membantu perogram pemerintah untuk mencerdaskan bangsa dan mengurangi pengangguran. ${ }^{30}$ Kedua rekontruksi admitrasi dan fisik pesantren secara besar-besaran karena perubahan dalam konteks ini sama sekali kurang bersinggungan dengan persoalan etis pesantren, kecuali peran bdan fungsi dan kharisma kiai harus dipertimbangkan kembali untuk dirubah sesuai etika modern yang mengedepankan asas profisionalitas dan kepastian hukum. Bukan berarti pesantren menulak profisionalitas dan asas kepastian hukumnamun hal ini harus didialogkan kembali dengan tradisi dan kultur masing-masing pesantren karena bagi Gus Dur pada realitasnya banyak pesantren yang masih tergantung pada figur karismatik kiai yang melegenda

Ketiga relasi hubungan antara masyarakat dan pesantren yang harus dikembangkan sesuai dengan kebutuhan zaman, Gus Dur mencopntohkan diera kolonial (awal pembentukan pesantren) lembaga pendidikan pesantren menjadi tempat perjuangan masyarakat. Dalam hal ini Gus Dur mencontohkan dengan dimensi awal berdirinya pesantren tebuireng jombang, selain untuk menata moral masyarakat juga tujuan untuk merespon kegelisahan masyarakat saat trejadi polemik dengan pabrik gula milik belanda. Kemudian diera akhir tahun 1980-an pesantren menjembatani kepentingan pemerintah untuk menanggulangi pengangguran pada saat itu hampir 10 persen terlibat langsung

${ }^{29}$ Ahmad Junaidi, Gus Dur Presiden Kyai Indonesia; Pemikiran Nyentrik Dari Pesantren Hingga Parlemen Jalanan (Surabaya: Diantama, 2010), 88.

${ }^{30}$ Wahid, Menggerakkan Tradisi, 212. 
dengan perogram pemerintah dalam melakukan pelatihan-pelatihan keterampilan, dan seterusnya.

Pesantren, sebagaimana yang kita ketahui adalah pranata (pendidikan) tradisional, sebagaimana pranata tradisional lainnya, pesantren sempat juga di curigai sebagai kejumudan, konservatisme. Ia menjadi penghalang besar bagi pembangunan, Gus Dur melalui esai-esai dan prasarana dan prasarananya seperti yang terkumpul dalam buku "Menggerakkan Tradisi" berusaha menepis dan mengklarifikasikan semua pandangan tersebut. Bagi Gus Dur sebagaiman yang diutarakan oleh Haris Salim HS dalam pengantar buku tersebut," pesantren sangat dinamis, bisa berubah dan mempunyai dasar yang kuat untuk ikut mengarahkan danmenggerakkan perubahan yang di inginkan", mungkin dalam konteks ini kita harus memahami dan memposisikan tradisi pesantren secara konferhensif ditengah derasnya arah modernisme. ${ }^{31}$

Berangakat dari optimisme yang besar terhadap potensi pesantren, Gus Dur menyambut positif berbagai tantangan baik dari internal maupun ekternal pesantren. Bahkan dengan sebutannya yang khas pesantren sebagai subkultur'. Gus Dur meletakkan pesantren tidak hanya sebagai identitas kultural yang hanya mampu menjadi ornamen pelengkap dalam dalam konstalasi-siklus dalam perubahan sosial, akan tetapi bagi Gus Dur pesantren memiliki kekuatan potensial untuk menjadi agen vital dalam melakukan perubahan ditengah masyarakat (agent of change)

Dalam kontek ini menjadi penting dalam dunia pendidikan pesantren agar mengembangkan berbagai potensi yang dimilinya untuk kemudian dapat dijadikan sebagai lngkah paradigmatik sekaligus strategi bagi pencegahan dan penanganan timbulnya komflik dimasyarakat yang selama ini adalah adanya paradigma keberagamaan yang masih eksklusif. Eksklusifisme masyarakat tersebut tampak dalam pola pikir beragama yang relatif masih dispariasitas, dan masih terdapat sekat-sekat primordialisme. Oleh karena itu, dibutuhkan paradigma baru dalam mengatur hubungan tersebut.

Hal ini tentunya merupakan sebuah upaya memanfaatkan nilai-nilai positif dan ruh fiqih-sufisme yang selama ini menjadi main stream masyarakat pesantren, uintyuk kemudian dapat dijadikan faktor utama pendorong masyarakat secara paradigmatik (prime mover) yang di proyeksikan dapat mengatasi berbagai persoalan yang ada di masyarakat tak terkecuali masalah

31 Setidaknya terjadi tiga alasan yang bisa menempatkan kebudayaan sebagai alat yang memungkinkan pembangunan bisa berjalan dengan sukses.1) unsur-unsur budaya yang mempunyai legitimasi tradisional dimata orang-orang yang menjadi sasaran pembangunan,2) unsur-unsur budaya secara simbolis merupakan bentuk komonikasi paling berharga dari penduduk setempat,3) unsur-unsur budaya memiliki aneka ragam fungsi yang menjadikannya sebagai sarana paling berharga untuk perubahan. Lihat Nat. J. Colletta, Kebudayaan Dan Pembangunan; Sebuah Pendekatan Terhadap Antropologi Terapan di Indonesia (Jakarta: Yayasan Obor, 1987), 5-6.

Jurnal Pendidikan Agama Islam

Volume 4 Nomor 2 Nopember 2016

ISSN(p) 2089-1946\& ISSN(e) 2527-4511

Hal. 244 - 248 
diintegerasi umat yang diakibatkan oleh kesalah pahaman memaknai nilai-nilai kemanusiaan yang ada dalam agama itu sendiri.

Di internal pesantren, manifestasi pengalaman ajaran fiqih yang menekankan nilai-nilai universal dan menghargai tegaknya nilai-nilai kemanusiaan pada dasarnya bukan merupakan hal yang baru, karena secara historis geniologis, universalitas dan humanitas sendiri merupakan akar keilmuan dan latar belakang pembentukan tata nilai dunia pesantren yang berkarakter, berciri khas dan memiliki ke unikan tersendiri, sebagaimana diutarakan oleh Abdurrahman Wahid dalam tulisannya yang berjudul "Asal-Usul Tradisi Keilmuan di Pesantren" ia mengatakan:

"Kombinasi dati nilai Humanisme dan kecendrungan normatif untuk tetap memperlakukan Al-Qur'an dan hadist sebagai sumber formal yang dilakukan oleh ulama' salaf ash shalih, menunjukkan peraktek humanisme dalam arti yang cukup luas, akan tetapi, semua itu berangsur-angsur menjadi kendur, ketika kendala normatif akhirnya menjadi terlalu besar fungsinya, sedangkan kendala penyerapan (menunjuk filsafat yunani dan penggunaan akal) mengecil fungsinya" 32

Oleh karena itu, mengembangkan nalar berfikir inklusif dan humanis, secara paradigmatik sangat diperlukan dilingkungan pendidikan pesantren, selain keduanya tidak bertentangan dengan nilai-nilai inti yang terkandung dalam akar tradisi dan keilmuan pesantren, hal ini juga diperlukan bagi pesantren sebagai pola pandang (paradigma) dalam melihat moderenisme sekaligus mengembaluikan peran vital pesantren sebagai agen perubahan dimasyarakat. Dan juga perlu pengembangan Nilai Hak Asasi Manusia

Abdurrahman Wahid mengertikan Humanisme sebagai bentuk pengakuan atas martabat kemanusiaan yang harus dijunjung tinggi, kapanpun, dimanapun dan oleh siapapun. Nilai kemanusiaan ini kemudiaan menjadi semacam common platfom bagi pertemuan segala bentuk perbedaan yang melatar belakanginya, baik suku, bahasa, RAS maupun Agama.

Sebagaimana yang dikatakan dalam buku Islam Kosmopolitan, Gus Dur mengatakan bahwa; humanisme Islam penampakan diri dalam berbagai manivestasi ajaran-ajarannya. Rangkaian ajaran yang meliputi berbagai bidang, seperti hukum Agama (fiqih), Keimanan (Tauhid) serta etika (akhlaq) seringkali disempitkan oleh masyarakat hingga hanya menjadi kesulitan dalam sikap hidup. Padahal unsur-unsur itulah yang sesungguhnya menampilkan kepedulian yang sangat besar kepada unsur-unsur utama dari kemanusiaan (al-insaniyah) perinsip-perinsip seperti persamaan derajat, perlindungan hukum, menjaga hak masyarakat lemah menurut Gus Dur merupakan kepedulian sifat humanisme Islam yang ada pada tiap agama tentu demikian adanya.

32 Wahid, Menggerakkan Tradisi, 219-220. 
Dengan kata lain, Gus Dur ingin menampilkan kepada kita bahwa strereotype beberapa kalangan yang mengatakan bahwa aspek tertentu pada diri pesantren terdapat kejumudan. Dalam konteks ini Abdurrahman Wahid ini membuka bahwa beberapa ajaran yang ada didalam pesantren sesunguhnya sangat menghargai hak-hak dan nilai dasar kemanusiaan,

Di Islam itu sendiri salah satu ajaran yang dengan sempuran menampilkan sifatnya secara humanis adalah lima buah jaminan dasar yang diberikan kepada warga masyarakat baik secara perorangan maupun secara kelompok. Dan jaminan dasar tersebut menurut Gus Dur terdapat dalam literatur fiqih kuno yang selama bertahun-tahun dipelajari dibeberapa pesantren secara turun temurun. Jaminan hak dasar tersebut adalah: 1) seselamatn fisik warga masyarakat dari tindakan badani diluar ketentuan hukum (hifdzu an-nafs); 2) keselamatan keyakinan masing-masing, tampa ada paksaan untuk berpindah agama (hifzu ad-din); 3) keselamatan keluarga dan keturunan (hifzu an-nasl); 4) keselamatan harta benda dan milik peribadi dari gangguan atau penggusuran diluar prosedur hukum (hifzu al-mal); dan 5) keselamatan hak milik dan profesi (hifzu al-aqli).

Namun dalam melihat hubungan antara Islam dan hak asasi manusia, sebagai mana diutarakan oleh M. Syafi'i Anwar, Gus Dur mempersoalkan klaim sejumlah pemikir dan pemimpin dunia Islam yang menyatakan Islam adalah agama yang paling demokratis dan amat menghargai hak asasi manusia. Ironisnya kenyataan yang ada justru berbedaa dengan klaim tersebut,33 padahal secara keilmuan Islam, nilai-nilai kemanusiaan sangat dijunjung tinggi terutama dalam literatur hukum fiqih klasik yang terdapat dalam pesantren.

Pada konteks ini, Gus Dur kemungkinan besar ingin pemperlihatkan kepada dunia bahwa pesantren dengan stereotypenya yang amat mendiskreditkan pesantren sendiri, sesungguhnya memiliki gagasan yang selaras dengan filsafat kehidupan dunia. Khusunya dalam persoalan menjaga dan menghargai nilai-nilai kemanusiaan, hal ini terbukti setiap kali Gus Dur mengeluarkan statemen, gagasan dan pemeikirannya selalu mengambil literatur dari pesantren.

\section{F. Kesimpulan}

Membaca pemikiran KH. Abdurrahaman wahid (Gus Dur) berarti membaca samudra keilmuan yang luas cakupannya. Dalam hal pesantren, menurut Gus Dur, pesantren harus mempertahankan identitas dirinya sebagai penjaga tradisi keilmuan klasik, dalam arti tidak larut sepenuhnya dengan modernisasi. Hal ini dimaksudkan supaya pesantren mencetak ahli ilmu agama Islam, pesantren juga

33 Abdurrahman Wahid, Islamku Islam Anda Islam Kita; Agama Masyarakat Negara Demokrasi (Jakarta: The Wahid Institute, 2006), xxi.

Jurnal Pendidikan Agama Islam

Volume 4 Nomor 2 Nopember 2016

ISSN(p) 2089-1946\& ISSN(e) 2527-4511

Hal. 246 - 248 
mampu mencetak orang yang memiliki keahlian dalam ilmu pengetahuan dan teknologi yang berguna untuk perkembangan masyarakat itu sendiri. Gus Dur, menginginkan ada perubahan pada kurikulum pesantren. Menurutnya, kurikulum pesantren selain harus kontekstual dengan kebutuhan zaman juga harus mampu merangsang daya intelektual-kritis anak didik. Bentuk kurikulum tersebut tetap harus dalam asas yang bermanfaat bagi masyarakat dan juga tidak sampai menghilangkan identitas diri pesantren sebagai lembaga pendidikan agama. Sebuah kurikulum mengajarkan agama saja, tetapi keduanya harus dalam porsi yang seimbang.

Secara esensial, pesantren menyandarkan diskursusnya pada epistemologi kitab kuning. Kitab kuning difungsikan oleh kalangan pesantren sebagai referensi nilai universal dalam menyikapi segala tantangan kehidupan. Karena itu, kitab kuning harus tetap terjaga. Kitab kuning dipahami sebagai mata rantai keilmuan Islam yang dapat bersambung hingga pemahaman keilmuan Islam masa tabiin dan sahabat hingga sampai pada nabi Muhammad. Makanya, memutuskan mata rantai kitab kuning, sama artinya membuang sebagian sejarah intelektual umat. Kitab kuning yang dikaji di pesantren tersebut hampir semuanya merupakan ilmu-ilmu yang berbasis pada epistemologi bayani dan irfani. Epistemologi bayani adalah sistem pengetahuan eksplikasi dalam bidang bahasa, fikih, ushul fiqh, kalam, dan balaghah. Gagasan Abdurrahman Wahid tentang dunia pendidikan pesantren merupakan upayanya untuk mengembangkan watak berfikir inklusif dan humanis yang secara historis merupakan akar tradisi keilmuan pesantren yang selama berabad-abad terpendam karena terlalu dominannya nalar berfikir normatif yang selama ini ada di pesantren.

\section{G. Referensi}

Abdullah, M. Amin. Islamic Studies di Perguruan Tinggi Pendekatan Integratif Interkonektif. Yogyakarta: Pustaka Pelajar, 2006.

Ahkamul Fuqoha, Solusi Problematika Aktual Hukum Islam Keputusan Muktamar, Munas dan Konbes NU (1926-1999). Surabaya: LTNU Jatim dan Diantama Lembaga Studi dan Pengembangan Pesantren, 2005.

Ali, Abdullah. Pemikiran Politik Islam dari Masa Nabi Hingga Masa Kini (Jakarta: Serambi Ilmu Semesta, 2001.

Colletta, Nat. J. Kebudayaan Dan Pembangunan; Sebuah Pendekatan Terhadap Antropologi Terapan di Indonesia. Jakarta: Yayasan Obor, 1987.

Fazlurrahman. Membaca Pintu Ijtihad, terj. Mahyuddin. Bandung: Penerbit Pustaka, 1984. 
Abdullah

Junaidi, Ahmad. Gus Dur Presiden Kyai Indonesia; Pemikiran Nyentrik Dari Pesantren Hingga Parlemen Jalanan. Surabaya: Diantama, 2010.

Martin, Burinessen Van. Rakyat Kecil, Islam Dan Politik. Yogjakarta: Yayasan Benteng Budaya, 1985.

Nata, Abudin. Tokoh-tokoh Pembaharuan Pendidikan Islam di Indonesia. Jakarta: Raja Grafindo Persada.

Santoso, Listiyono. Teologi Politik Gus Dur. Jogjakarta: Ar-Ruzz, 2004.

Shaleh, Sonhaji. Dinamika Pesantren, Kumpulan Makalah Seminar Internasional, The Role of Pesantren in Education and Community Development in Indonesia. Jakarta : P3M, 1988.

Siradj, Said Aqil. pesantren Masa Depan, Wacana Pemberdayaan Dan Transformasi Pesantren. Bandung: Pustaka Hidayah, 1999.

Subki (al), Tajudin 'Abdul Wahhab Ibn 'Ali. Jam'ul Jawami' Fi Usulil Fiqh. Nairab Damaskus, $771 \mathrm{H}$.

Tolkhah, Imam dan Barizi, Ahmad. Membuka Jendela Pendidikan; Mengurai Akar Tradisi. Jakarta: Raja Grafindo Persada, 2004.

Wahid, Abdurrahman. Gus Dur Bertutur. Jakarta: Harian Proaksi dan Gus Dur Fodation, 2005.

. Islamku Islam Anda Islam Kita; Agama Masyarakat Negara Demokrasi. Jakarta: The Wahid Institute, 2006. . Menggerakkan Tradisi. Jogjakarta: LKIS, 2001. . Pribumisasi Islam. Yogyakarta: LKiS, 1998. 